\title{
In vivo reactivation of catechol 2,3-dioxygenase mediated by a chloroplast-type ferredoxin: a bacterial strategy to expand the substrate specificity of aromatic degradative pathways
}

\author{
Alessandra Polissi and Shigeaki Harayama \\ Department of Medical Biochemistry, Faculty of Medicine, \\ 1, rue Michel-Servet, 1211 Geneva 4, Switzerland \\ Communicated by K.N.Timmis
}

The meta-cleavage operon of the TOL plasmid pWW0 of Pseudomonas putida contains 13 genes responsible for the oxidation of benzoate and toluates to Krebs cycle intermediates via extradiol (meta) cleavage of (methyl)catechol. The functions of all the genes are known with the exception of $x y l T$. We constructed pWWO mutants defective in the $x y l T$ gene, and found that these mutants were not able to grow on $p$-toluate while they were still capable of growing on benzoate and $\boldsymbol{m}$-toluate. In the $x y l T$ mutants, all the meta-cleavage enzymes were induced by $p$-toluate with the exception of catechol 2,3-dioxygenase whose activity was $1 \%$ of the $p$-toluateinduced activity in wild-type cells. Addition of 4-methylcatechol to $m$-toluate-grown wild-type and $x y l T$ cells resulted in the inactivation of catechol 2,3-dioxygenase in these cells. In the wild-type strain but not in the $x y l T$ mutant, the catechol 2,3-dioxygenase activity was regenerated in a short time. The regeneration of the catechol 2,3-dioxygenase activity was also observed in $\mathrm{H}_{2} \mathrm{O}_{2}$-treated wild-type cells, but not in $\mathrm{H}_{2} \mathrm{O}_{2}$-treated $x y l T$ cells. We concluded that the $x y l T$ product is required for the regeneration of catechol 2,3-dioxygenase.

Key words: catechol 2,3-dioxygenase/enzyme reactivation/Pseudomonas putida/TOL plasmid/xylT

\section{Introduction}

The TOL plasmid pWW0, originally found in Pseudomonas putida mt-2, carries a set of genes responsible for the mineralization of toluene, $m$-xylene and $p$-xylene (Worsey and Williams, 1975). The genes are organized into two operons 'upper' and 'meta' (Harayama et al., 1984; Harayama and Rekik, 1990). The upper operon encodes three enzymes which transform toluene, $m$-xylene and $p$-xylene to benzoate, $m$-toluate and $p$-toluate, respectively (Harayama et al., 1986, 1989). The meta operon, on the other hand, comprises 13 genes, xylXYZLTEGFJQKIH (Nakazawa et al., 1980; Harayama et al., 1987; Harayama and Rekik, 1990). The first four genes of the meta operon, $x y l X Y Z L$, are involved in the oxidation of benzoate, $m$-toluate and $p$-toluate to catechol, 3-methylcatechol and 4-methylcatechol, respectively, while the $x y l E G F J Q K I H$ genes are required for the transformation of these catechols into Krebs cycle intermediates. As shown in Figure 1, the functions of all the meta operon genes are known except $x y l T$ which is located between the $x y l X Y Z L$ and $x y l E G F J Q K I H$ clusters (Harayama et al., 1991a). Isofunctional genes to $x y l T E G F$ $J Q K I H$ are found in the sal operon on the NAH7 plasmid responsible for the mineralization of salicylate (Yen and Gunsalus, 1982; You et al., 1991), and in the dmp operon on the pVI150 plasmid responsible for the mineralization of (dimethyl)phenol (Bartilson et al., 1990; Nordlund et al., 1990; Shingler et al., 1992). The gene orders and DNA sequences are highly conserved between $x y l T E G F J Q K I H$ and their homologues in the sal and dmp operons (Shingler $e t$ al., 1992; Harayama and Rekik, 1993). The nahT gene on the NAH7 plasmid and the $d m p Q$ gene on the pVI150 plasmid are equivalent to the $x y l T$ gene on the $\mathrm{pWW} 0$ plasmid, and the amino acid sequences of these gene products all possess a motif characteristic of chloroplast-type ferredoxins (Harayama et al., 1991a; You et al., 1991; Shingler et al., 1992).

Since the $x y l T$, nahT and $d m p Q$ genes have been evolutionarily conserved in three different operons involved in the degradation of catechols, we expected that the $x y l T / n a h T / d m p Q$ products may have some important role in the mineralization of catechols. Here we describe the isolation and characterization of pWW0 mutants defective in $x y l T$. We found that the $x y l T$ product was involved in the regeneration of inactivated catechol 2,3-dioxygenase, and that the regeneration was indispensable for the growth of the host cells on $p$-xylene, $p$-methylbenzyl alcohol and $p$ toluate.

\section{Results}

\section{Construction of xylT mutants of pWWO}

The $6 \mathrm{~kb}$ EcoRI-PstI fragment containing the $x y l X Y Z L T E G$ sequence of TOL plasmid pWW0 (Figure 2) was subcloned into pACYC184 to form pGA1. The pGA1 plasmid is resistant to tetracycline $\left(\mathrm{Tc}^{\mathrm{R}}\right)$. The 1.2 kanamycin $(\mathrm{Km})$ cassette from pRME1 was inserted into the NcoI site of pGA1 within the $x y l T$ gene to create the $x y l T 1:: \mathrm{Km}^{\mathrm{R}}$ mutation. The pGA2 plasmid thus constructed is $T^{R}, \mathrm{Km}^{\mathrm{R}}$. This plasmid was used to transform Escherichia coli strain LE392 harboring pWW0-161. The pWW0-161 plasmid carries transposon $\mathrm{Tn} 401$, and confers resistance to ampicillin $\left(\mathrm{Ap}^{\mathrm{R}}\right)$. LE392(pWW0-161, pGA2) transformants were therefore selected for $\mathrm{Ap}^{\mathrm{R}}, \mathrm{Km}^{\mathrm{R}}$. LE392(pWW0-161, pGA2) was then mated with E.coli GSH3491 to isolate spectinomycin resistant $\left(\mathrm{Sp}^{\mathrm{R}}\right.$, selection for GSH3491), $\mathrm{Ap}^{\mathrm{R}}$ (selection for $\mathrm{pWW}$ ) and $\mathrm{Km}^{\mathrm{R}}$ (selection for pGA2) transconjugants. Since pACYC184 is neither conjugative nor mobilizable, the transfer of pGA2 from LE392(pWW0-161, pGA2) to the GSH3491 recipient may have resulted from cointegrate formation between the conjugative pWW0-161 and plasmid pGA2. Theoretically, a cointegrate of these two plasmids can be formed either by homologous recombination or by the transposition of $\operatorname{Tn} 401$ onto pGA2. If a cointegrate was formed by the homologous recombination, its resolution into two plasmids through the second homologous recombination may have eventually exchanged the 
$x y l T 1:: \mathrm{Km}^{\mathrm{R}}$ allele of $\mathrm{pGA} 2$ for the $x y l T^{+}$allele of pWW0-161.

Ten independent $\mathrm{Sp}^{\mathrm{R}}, \mathrm{Ap}^{\mathrm{R}}, \mathrm{Km}^{\mathrm{R}}$ transconjugants of GSH3491 were mated with P.putida KT2440, and $\mathrm{Km}^{\mathrm{R}}$ transconjugants were selected on benzoate M9 minimal plates. KT2440 is a prototroph and encodes an ortho pathway that allows this strain to grow on benzoate (but not on $m$-toluate and $p$-toluate). The $\mathrm{Km}^{\mathrm{R}}$ transconjugants of KT2440 were $\mathrm{Tc}^{\mathrm{S}}$ indicating that the wild-type $x y l T$ allele was replaced by the $x y l T 1:: \mathrm{Km}^{\mathrm{R}}$ allele in these transconjugants.

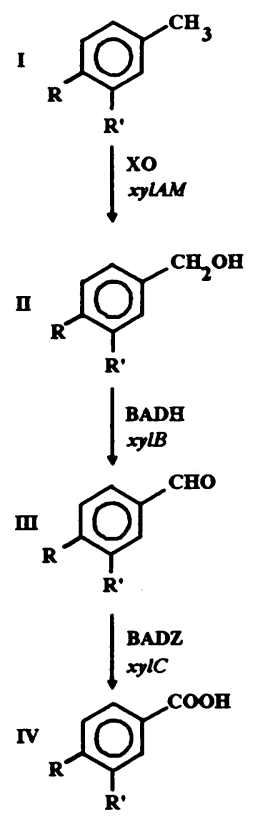<smiles>[R]c1ccc(C(=O)O)cc1[R]O[Na]</smiles>

$\mathbf{v}$

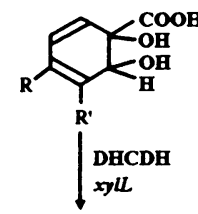

II<smiles>[R]c1ccc(O)c(O)c1[R]</smiles>
$\mid \begin{aligned} & \text { C230 } \\ & x y 1 E\end{aligned}$

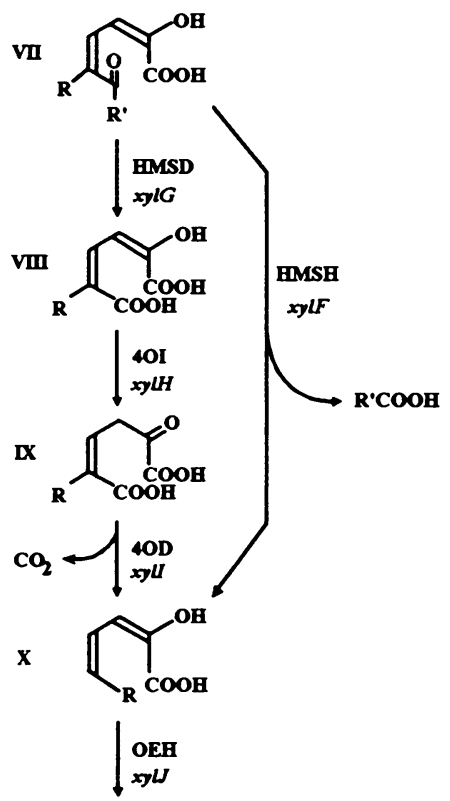<smiles>[R]CC(CC(=O)O)CC(=O)O</smiles>

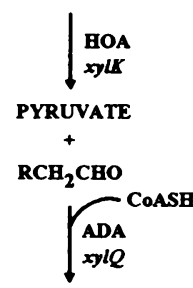

$\mathrm{RCH}_{2} \mathrm{COCOA}$
These P.putida $\mathrm{Km}^{\mathrm{R}}$ transconjugants grew on toluene, benzyl alcohol, benzoate, $m$-xylene, $m$-methylbenzyl alcohol and $m$-toluate, but did not grow on $p$-xylene, $p$-methylbenzyl alcohol and $p$-toluate.

The enzymes of the meta pathway, namely catechol 2,3-dioxygenase, hydroxymuconic semialdehyde dehydrogenase and hydroxymuconic semialdehyde hydrolase coded for by $x y l E, x y l G$ and $x y l F$, respectively, were not induced by $m$-toluate, but expressed constitutively in these P.putida $\mathrm{Km}^{\mathrm{R}}$ transconjugants (data not shown). This observation indicated that the $x y l T 1:: \mathrm{Km}^{\mathrm{R}}$ mutation on $\mathrm{pWW} 0$ exhibits a polar effect on the genes downstream of $x y l T$. Therefore the observed phenotype of P.putida KT2440(pWW0-161 $x y l T 1:: \mathrm{Km}^{\mathrm{R}}$ ), namely the absence of growth on $p$-xylene and its alcohol and carboxylate derivatives, may not necessarily be due to the defect in the $x y l T$ gene itself, but to the altered expression of the meta operon genes downstream of $x y l T$. In order to construct non-polar $x y l T$ mutations, plasmid pGA1 was cleaved at the unique $\mathrm{NcoI}$ site located within $x y l T$, the $N c o$ I cohesive ends thus created were filled with Klenow polymerase, and the linearized DNA was either directly ligated to form pGA4 plasmid, or ligated with a 7 bp long linker (5'-AAGCTTG-3') to form pGA3 plasmid. The $x y l T$ mutations thus constructed in pGA3 and pGA4 were called $x y l T 2$ and $x y l T 3$ respectively.

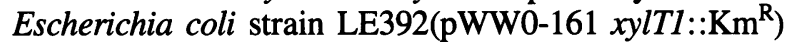
was transformed either by pGA3 or pGA4, and the $\mathrm{Tc}^{\mathrm{R}}$ marker of pGA3 and pGA4 in LE392(pWW0-161 $x y l T 1:: \mathrm{Km}^{\mathrm{R}}$, pGA3) or LE392(pWW0-161 $x y l T 1:: \mathrm{Km}^{\mathrm{R}}$, pGA4), was conjugally transferred into GSH3491. Tc ${ }^{\mathrm{R}}$ transconjugants derived from GSH3491 were further conjugated with $P$.putida KT2440, and KT2440 derivatives that grow on $m$-xylene $\left(m-\mathrm{Xyl}^{+}\right)$were selected [the growth

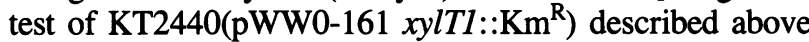
indicated that the $x y l T$ mutation on pWW0 does not affect the growth of $P$.putida on $m$-xylene]. Among the $m$-Xyl ${ }^{+}$ transconjugants, those containing $\mathrm{pWW} 0-161$ carrying the $x y l T 2$ or $x y l T 3$ allele instead of the $x y l T 1:: \mathrm{Km}^{\mathrm{R}}$ allele were expected to exist. The $m-\mathrm{Xyl}^{+}$transconjugants were

Fig. 1. The $x y l$ operons for the catabolism of $m$-toluate, $p$-toluate and benzoate encoded by TOL plasmid pWW0 of P.putida. Enzyme abbreviations: XO, xylene monooxygenase; BADH, benzyl alcohol dehydrogenase; BZDH, benzaldehyde dehydrogenase; TO, toluate 1,2-dioxygenase; DHCDH, 1,2-dihydroxycyclohexa-3,5-dienecarboxylate dehydrogenase; C230, catechol 2,3-dioxygenase; HMDS, hydroxymuconic semialdehyde dehydrogenase; HMSH, hydroxymuconic semialdehyde hydrolase; 4OI, 4-oxalocrotonate isomerase; 4-OD, 4-oxalocrotonate decarboxylase; OEH, 2-oxopent-4-enoate hydratase; HOA, 4-hydroxy-2-oxovalerate aldolase; ADA, acetaldehyde dehydrogenase (acetylating). $x y l E-x y l Z$ are the designations of the structural genes for the catabolic enzymes. Compounds: for $\mathbf{R}=\mathbf{H}$, $\mathbf{R}^{\prime}=\mathrm{H}$, (I) toluene; (II) benzyl alcohol; (III) benzaldehyde; (IV) benzoate; (V) 1,2-dihydroxycyclohexa-3,5-dienecarboxylate; (VI) catechol; (VII) 2-hydroxymuconic semialdehyde; (VIII) 2-hydroxyhexa-2,4-diene-1,6-dioate; (IX) 2-oxohex-4-ene-1,6-dioate; (X) 2-oxopent-4-enoate; for $\mathbf{R}=\mathbf{H}, \mathbf{R}^{\prime}=\mathrm{CH}_{3}$, (I) $m$-xylene; (II) $m$-methylbenzyl alcohol; (III) $m$-methylbenzaldehyde; (IV) $m$-toluate; (V) 1,2-hydroxy-3-methylcyclohexa-3,5-dienecarboxylate; (VI) 3-methylcatechol; (VII) 2-hydroxy-6-oxohepta-2,4-dienoate; (X) 2-oxopent-4-enoate; for $\mathbf{R}=\mathrm{CH}_{3}, \mathrm{R}^{\prime}=\mathrm{H}$, (I) $p$-xylene; (II) $p$ methylbenzyl alcohol; (III) $p$-methylbenzaldehyde; (IV) $p$-toluate; (V) 1,2-dihydroxy-4-methylcyclohexa-3,5-dienecarboxylate; (VI) 4-methylcatechol; (VII) 2-hydroxy-5-methyl-6-oxohexa-2,4-dienoate; (VIII) 2-hydroxy-5-methylhexa-2,4-diene-1,6-dioate; (IX) 5-methyl-2-oxohex-4-ene-1,6-dioate; (X) 2-oxo-cis-hex-4-enoate. 
therefore tested for their sensitivity to $\mathrm{Km}$, and $\mathrm{Km}^{\mathrm{S}}$ clones were found at a frequency of $2 \times 10^{-2}$.

All the $\mathrm{Km}^{\mathrm{S}}$ transconjugants of KT2440 showed the same phenotype as KT2440(pWW0-161 $x y l T 1:: \mathrm{Km}^{\mathrm{R}}$ ): they grew on toluene, $m$-xylene and their alcohol and carboxylate derivatives, but did not grow on $p$-xylene and its alcohol and carboxylate derivatives. Each one of the putative pWW0-161 $x y l T 2$ and pWW0-161 xylT3 plasmids was isolated and their $x y l T$ sequences were determined: they carried the expected $x y l T$ mutations.

\section{The meta pathway enzyme activities in the xylT2 and xy/T3 mutants}

The activities of four meta operon enzymes, catechol 2,3-dioxygenase, hydroxymuconic semialdehyde hydrolase, hydroxymuconic semialdehyde dehydrogenase and 4-oxalocrotonate tautomerase were assayed in KT2440(pWW0-161), KT2440(pWW0-161 xylT2) and KT2440(pWW0-161 xylT3) grown in glucose M9 minimal medium containing either $m$-toluate or $p$-toluate as an inducer. In the $x y l T$ mutants induced by $m$-toluate, the activities of the tested enzymes were comparable with those of the wild-type strain with the exception of the catechol 2,3-dioxygenase activity which was half the wild-type activity (Table I). More strikingly, the $x y l T$ mutants grown in the presence of $p$-toluate showed a catechol 2,3-dioxygenase activity $<1 \%$ of the wild-type activity although the levels of other meta pathway enzymes were similar to those in the wild-type strain (Table I). The lower catechol 2,3-dioxygenase activity in the $x y l T$ mutants upon the growth with $p$-toluate was not explained by the failure of the induction of catechol 2,3-dioxygenase by $p$ toluate because other meta pathway enzymes encoded in the

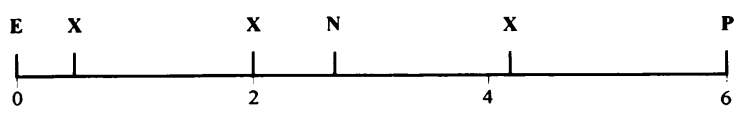

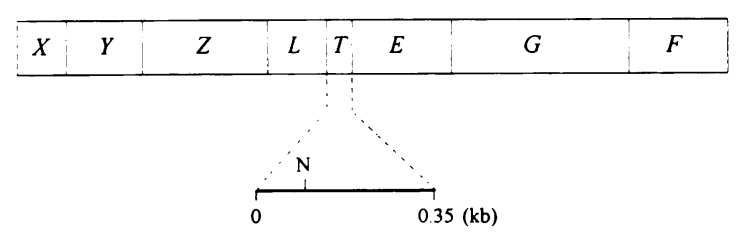

Fig. 2. Physical and genetic map of the $x y l T$ region on TOL plasmid pWW0. Restriction sites are: E, EcoRI; N, NcoI; P, PstI; and X, $X$ hoI. Open boxes represent structural genes (Harayama and Rekik, 1990). same operon were induced. The possibility that the $x y l T$ product is required for the post-translational activation of catechol 2,3-dioxygenase was ruled out since a significant catechol 2,3-dioxygenase activity was observed in the $x y l T$ mutants grown in the presence of $m$-toluate. We therefore expected that catechol 2,3-dioxygenase in the $x y l T$ mutants was inactivated during the growth on $p$-toluate.

\section{The inactivation and reactivation of catechol 2,3-dioxygenase in vivo}

The results described above suggested that catechol 2,3-dioxygenase in the $x y l T$ mutants was inactivated by a metabolite of $p$-toluate. We tested the possibility that 4-methylcatechol could inactivate catechol 2,3-dioxygenase in the $x y l T 2$ mutant. When the wild-type and $x y l T 2$ cells were grown in $m$-toluate M9 minimal medium, catechol 2,3-dioxygenase activity expressed in the xylT2 cells was $\sim 50 \%$ of the wild-type level (Figure 3B). When $2 \mathrm{mM}$ 4-methylcatechol was added to the $x y l T 2$ strain grown at a mid-exponential growth phase, the catechol 2,3-dioxygenase activity in the $x y l T 2$ cells rapidly dropped to zero, and the activity lost was not recovered during the next $18 \mathrm{~h}$ cultivation (Figure 3D). The culture of the $x y l T 2$ mutant turned to black $6 \mathrm{~h}$ after the addition of 4-methylcatechol; this may be due to the spontaneous polymerization of 4-methylcatechol. The addition of 4-methylcatechol to the wild-type culture also resulted in the rapid decrease in the catechol 2,3-dioxygenase activity within $2 \mathrm{~h}$, but the activity started to reincrease $4 \mathrm{~h}$ after the addition of 4-methylcatechol. The wild-type culture become yellow after the addition of 4-methylcatechol suggesting the accumulation of the ring-cleavage product of 4-methylcatechol, but unlike the $x y l T 2$ culture, the development of the black color was not observed. Hence most of the exogenous 4-methylcatechol was rapidly metabolized in the wild-type culture. When 3-methylcatechol was added, only slight and temporal decrease in the catechol 2,3-dioxygenase activity was observed both in the wild-type and $x y l T 2$ cultures (Figure $3 F)$. These observations explained why the $x y l T$ mutants do not grow on $p$-xylene, $p$-methylbenzyl alcohol or $p$-toluate but do grow on $m$-xylene, $m$-methylbenzyl alcohol and $m$ toluate.

\section{In vivo reactivation of catechol 2,3-dioxygenase}

Above, we observed that the addition of 4-methylcatechol to the wild-type and $x y l T$ cultures resulted in the inactivation of catechol 2,3-dioxygenase, and that the catechol 2,3-dioxy-

Table I. Activities ${ }^{\mathrm{a}}$ of meta pathway enzymes in wild-type and $x y l T$ mutant strains

\begin{tabular}{|c|c|c|c|c|c|c|c|c|c|c|c|c|c|c|}
\hline \multirow[t]{5}{*}{ Strain } & \multicolumn{4}{|c|}{$\mathrm{C} 230(x y l E)^{\mathrm{b}}$} & \multicolumn{4}{|c|}{ HMSH $(x y l F)$} & \multicolumn{4}{|c|}{ HMSD $(x y l G)$} & \multicolumn{2}{|c|}{ 40I $(x y l H)$} \\
\hline & \multicolumn{14}{|c|}{ Substrate } \\
\hline & \multirow{2}{*}{\multicolumn{2}{|c|}{ Catechol }} & \multirow{2}{*}{\multicolumn{2}{|c|}{$\begin{array}{l}\text { 4-methyl- } \\
\text { catechol }\end{array}$}} & \multicolumn{8}{|c|}{ Ring-cleavage product of } & \multirow{2}{*}{\multicolumn{2}{|c|}{ 4-oxalocrotonate }} \\
\hline & & & & & Cate & & & & Cate & & & & & \\
\hline & A & B & A & B & A & B & A & B & A & B & A & B & A & B \\
\hline WT & 5700 & 4100 & 5200 & 3500 & 59 & 22 & 21 & 10 & 71 & 47 & 78 & 42 & 1300 & 1200 \\
\hline$x y l T 2$ & 2800 & 10 & 2800 & 8 & 33 & 23 & 19 & 11 & 92 & 23 & 75 & 22 & 1500 & 1300 \\
\hline$x y l T 3$ & 2900 & 14 & 2900 & 34 & 40 & 32 & 23 & 16 & 87 & 27 & 73 & 32 & 1200 & 1400 \\
\hline
\end{tabular}

${ }^{a}$ Activities in crude extracts are expressed as nmol of product formed (or substrate consumed) per min per mg of protein.

${ }^{b}$ For abbreviation of meta pathway enzymes, see Figure 1.

A, $m$-toluate induced cells.

B, $p$-toluate induced cells. 

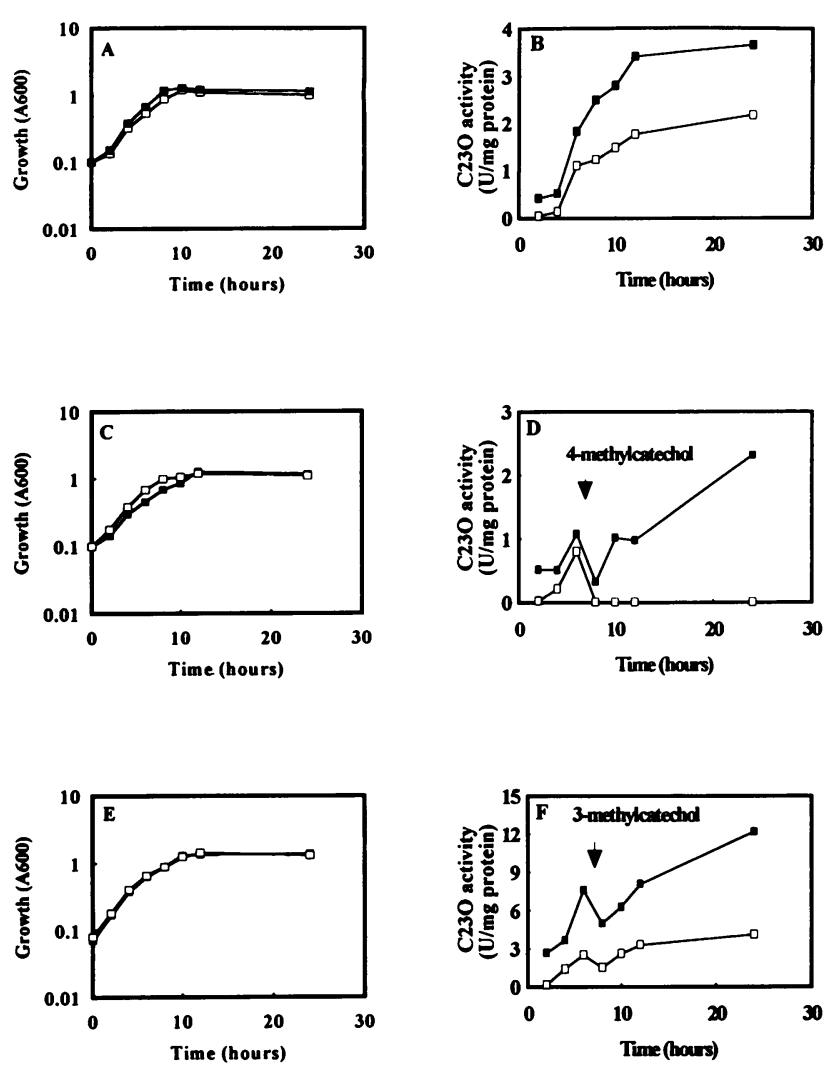

Fig. 3. Catechol 2,3-dioxygenase activities in the wild-type and $x y l T$ cells. Cultures of KT2440(pWW0-161) and of KT2440(pWW0-161 xylT2) were grown overnight in M9 minimal medium containing $5 \mathrm{mM}$ $m$-toluate. Overnight cultures were diluted into the fresh medium of the same composition. Growth measured by absorbance (A600) (A, C and E) and catechol 2,3-dioxygenase activity (C23O) (B, D and F) of the wild-type ( $\square)$ and $x y l T 2(\square)$ cells are presented. At $t=6 \mathrm{~h}, 2$ $\mathrm{mM}$ 4-methylcatechol (C and D) or $2 \mathrm{mM}$ 3-methylcatechol (E and F) was added to the cultures.

genase activity reincreased in a short period of time in the wild-type cells but not in the $x y l T$ cells. A plausible explanation of these observations was that wild-type cells, but not $x y l T$ cells, possess a mechanism to reactivate inactivated catechol 2,3-dioxygenase. To test this hypothesis, catechol 2,3-dioxygenase in chloramphenicol-treated cells was inactivated by treating them with $\mathrm{H}_{2} \mathrm{O}_{2}$, and subsequent regeneration of catechol 2,3-dioxygenase activity was observed in the wild-type and xylT2 cells. $\mathrm{H}_{2} \mathrm{O}_{2}$ has been shown to inactivate catechol 2,3-dioxygenase by oxidizing the catalytic center ferrous ion to the ferric form (Nozaki et al., 1968). The wild-type cells were capable of reactivating, within $10 \mathrm{~min}$, the inactivated catechol 2,3-dioxygenase up to $50 \%$ of the initial activity (Figure 4A). In contrast, no reactivation of catechol 2,3-dioxygenase occurred in the $x y l T 2$ mutant (Figure 4B). Our data thus demonstrated that the $x y l T$ product was necessary for the reactivation of catechol 2,3-dioxygenase inactivated either by 4-methylcatechol or by $\mathrm{H}_{2} \mathrm{O}_{2}$. The $x y l T$ product may reactivate catechol 2,3-dioxygenase by reducing the oxidized iron cofactor. The structure of the $x y l T$ product is consistent with this hypothesis: the $x y l T$ product has a structure similar to chloroplast-type ferredoxins (Harayama et al., 1991a) which are involved in many different electron transport processes (Bruschi and Guerlesquin, 1988).
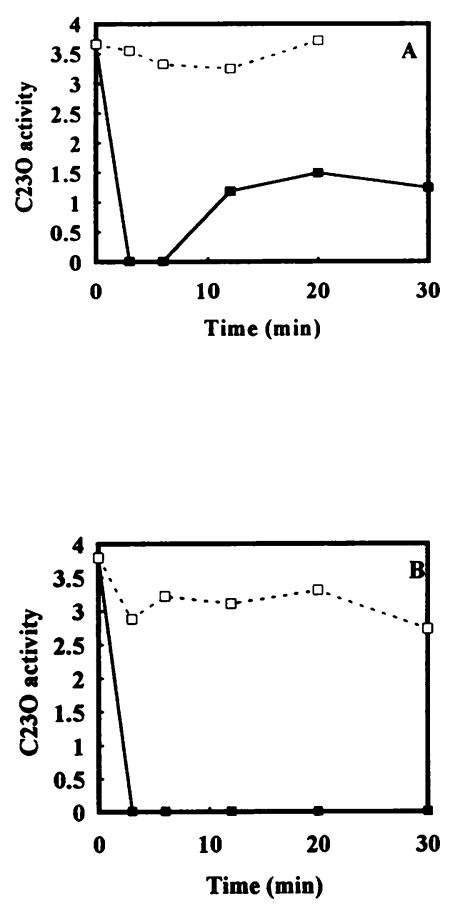

Fig. 4. Reactivation of catechol 2,3-dioxygenase inactivated by $\mathrm{H}_{2} \mathrm{O}_{2}$. KT2440(pWW0-161) and KT2440(pWW0-161 xylT2) cells were grown in $\mathrm{M} 9$ minimal medium containing $5 \mathrm{mM} m$-toluate, washed and resuspended in $0.1 \mathrm{M}$ potassium phosphate buffer $(\mathrm{pH} 7.4)$ containing $100 \mu \mathrm{g} / \mathrm{ml}$ chloramphenicol. After measuring the initial activity of catechol 2,3-dioxygenase, the cell suspensions of the wild-type and $x y l T 2$ strains were added by $50 \mu \mathrm{M} \mathrm{H}_{2} \mathrm{O}_{2}(t=0 \mathrm{~min}) .100 \mu \mathrm{l}$ aliquots were harvested at different times, and the catechol 2,3-dioxygenase activities in these samples were measured. (A) Wild-type cells inactivated $(\square)$ or not inactivated $(\square)$ by $\mathrm{H}_{2} \mathrm{O}_{2}$. (B) xylTl cells inactivated ( $\square$ ) or not inactivated $(\square)$ by $\mathrm{H}_{2} \mathrm{O}_{2}$. The catechol 2,3-dioxygenase activity is expressed as nmol catechol oxidized per $10^{7}$ cells per min. For experimental details see Materials and methods.

\section{Determination of the rate constants for catechol 2,3-dioxygenase inactivation}

All the results described above support the hypothesis that the inability of $x y l T$ mutants to grow on $p$-xylene, $p$ methylbenzyl alcohol and $p$-toluate is due to the inactivation of catechol 2,3-dioxygenase by 4-methylcatechol produced from these substrates. We then examined, in vitro, the inactivation of purified catechol 2,3-dioxygenase by 4-methylcatechol. Catechol 2,3-dioxygenase was purified from the wild-type strain and the $x y l T 2$ mutant as described in Materials and methods. When these enzymes were incubated with 4-methylcatechol in the absence of oxygen (another substrate of catechol 2,3-dioxygenase), neither catalytic reaction nor enzyme inactivation occurred. In the presence of oxygen, the ring-cleavage reaction took place, and the enzyme inactivation occurred concomitantly. The degree of the enzyme inactivation was estimated by determining the rate constant for the enzyme inactivation, $k_{\text {inact }}$. As shown in Table II, the $k_{\text {inact }}$ values of catechol 2,3-dioxygenase purified from the wild-type strain were identical to those of catechol 2,3-dioxygenase purified from the xylT2 mutant, using as substrates catechol, 3-methylcatechol and 4-methylcatechol (each one at a concentration of $50 \mu \mathrm{M})$. Therefore, it is unlikely that post-translational modification by the XylT product stabilizes catechol 2,3dioxygenase. As shown in Table II, catechol 2,3-dioxy- 
Table II. Kinetic constants for the inactivation of catechol 2,3-dioxygenase purified from wild-type and $x y l T 2$ strains

\begin{tabular}{lcl}
\hline Substrates & $\begin{array}{l}\text { C230 from wild-type } \\
k_{\text {inact }}\left(\mathrm{s}^{-1}\right)\end{array}$ & $\begin{array}{l}\mathrm{C} 230 \text { from xylT2 } \\
k_{\text {inact }}\left(\mathrm{s}^{-1}\right)\end{array}$ \\
\hline Catechol & $6 \times 10^{-4}$ & n.d. \\
3-methylcatechol & $2.8 \times 10^{-3}$ & $2.5 \times 10^{-3}$ \\
4-methylcatechol & $5.8 \times 10^{-3}$ & $5.2 \times 10^{-3}$ \\
\hline
\end{tabular}

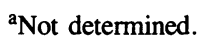

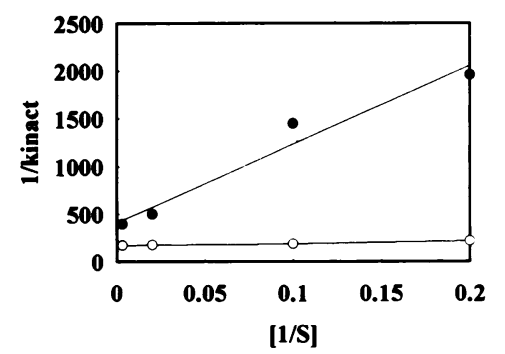

Fig. 5. Reciprocal plot of $k_{\text {inact }}$ versus the concentration of 3-methylcatechol $(\bullet)$ and 4-methylcatechol $(O)$ The $k_{\text {inact }}$ values for 4-methylcatechol at concentrations of $5,10,50$, and $300 \mu \mathrm{M}$ were $4.5 \times 10^{-3}, 5.3 \times 10^{-3}, 5.6 \times 10^{-3}$ and $5.7 \times 10^{-3} \mathrm{~s}^{-1}$, respectively. Those for 3-methylcatechol at these concentrations were $5.1 \times 10^{-4}, 6.9 \times 10^{-4}, 2.0 \times 10^{-3}$ and $2.5 \times 10^{-3} \mathrm{~s}^{-1}$, respectively.

genase was inactivated very little during the oxidation of catechol. Higher inactivation of the enzyme was observed in the oxidation of methyl-substituted catechols: the $k_{\text {inact }}$ for 4-methylcatechol was only 2-fold higher than that of 3-methylcatechol (Table II). We measured the $k_{\text {inact }}$ for methyl-substituted catechols at different concentrations: $k_{\text {inact }}$ values for 4-methylcatechol were almost constant at substrate concentrations between 5 and $300 \mu \mathrm{M}$ while those for 3-methylcatechol decreased as the substrate concentration decreased from 300 to $5 \mu \mathrm{M}$. From the reciprocal plot presented in Figure 5, it was shown that the concentration of 4-methylcatechol required for the half maximum of $k_{\text {inact }}$ was around $3 \mu \mathrm{M}$ while the concentration of 3-methylcatechol required for the half maximum of $k_{\text {inact }}$ was $>30 \mu \mathrm{M}$. Thus, although the $k_{\text {inact }}$ value for 3-methylcatechol at the concentration of $50 \mu \mathrm{M}$ was only 2-fold lower than that for 4-methylcatechol at the concentration of $50 \mu \mathrm{M}$, the $k_{\text {inact }}$ for 3-methylcatechol at the concentration of $5 \mu \mathrm{M}$ was 10-fold lower than that for 4-methylcatechol at the concentration of $5 \mu \mathrm{M}$. These data showed that 4-methylcatechol inactivated catechol 2,3-dioxygenase more strongly than 3-methylcatechol especially at low substrate concentrations, and explained the stronger effect of 4-methylcatechol than 3-methylcatechol in the catechol 2,3-dioxygenase inactivation observed in vivo (Figure 3).

\section{Inhibition of the catechol 2,3-dioxygenase activity by ring-cleavage products}

Previous studies (Hori et al., 1973) demonstrated that the ring-cleavage product of catechol (2-hydroxymuconic semialdehyde) was a non-competitive inhibitor for the oxidation of catechol by catechol 2,3-dioxygenase. Therefore, the stronger inhibition of the catechol 2,3-dioxygenase activity exerted by the addition of 4-methylcatechol than by the addition of 3-methylcatechol (Figure 3) may be partly
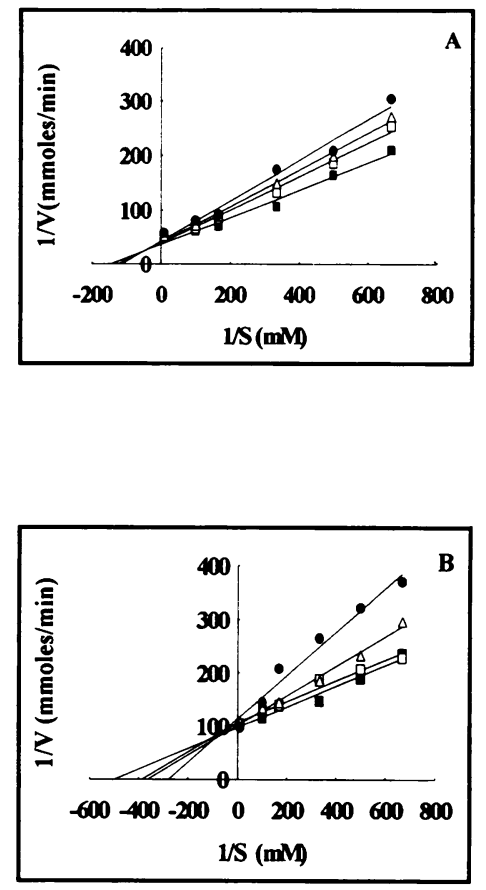

Fig. 6. Inhibition of the catechol 2,3-dioxygenase activity by the ringcleavage products of 3-methylcatechol and 4-methylcatechol. Lineweaver-Burk plots of initial rates of catechol oxidation in the presence of various concentrations of the ring-cleavage products are presented. The reaction was carried out in $1 \mathrm{ml}$ of $100 \mathrm{mM}$ potassium phosphate buffer (pH 7.4) in the presence of $0.08 \mu \mathrm{g}$ of enzyme. (A) The inhibition of the oxidation of 3-methylcatechol; the concentrations of 2-hydroxy-5-methyl-6-oxohexa-2,4-dienoate were: $82 \mu \mathrm{M}(\bullet)$, $53 \mu \mathrm{M}(\triangle), 34 \mu \mathrm{M}(\square), 0 \mu \mathrm{M}(\square)$. (B) the inhibition of the oxidation of 4-methylcatechol; the concentrations of 2-hydroxy-6oxohepta-2,4-dienoate were: $117 \mu \mathrm{M}(\bullet), 82 \mu \mathrm{M}(\triangle), 30 \mu \mathrm{M}(\square)$,

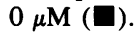

due to the stronger inhibition of the enzyme activity by the ring-cleavage product of 4-methylcatechol than by the ringcleavage product of 3-methylcatechol. We thus examined the inhibition of the catechol 2,3-dioxygenase-catalyzed oxidation of 4-methylcatechol and of 3-methylcatechol, respectively, by the ring-cleavage products of 4-methylcatechol (2-hydroxy-5-methyl-6-oxohexa-2,4-dienoate) and of 3-methylcatechol (2-hydroxy-6-oxohepta-2,4-dienoate). The kinetic analysis of the product inhibition shown in Figure $6 \mathrm{~A}$ and $\mathrm{B}$ demonstrated that the ring-cleavage products are competitive inhibitors. Replots of slopes of Figure 6A and $B$ versus the concentration of each inhibitor gave straight lines: the $K_{i}$ values for 2-hydroxy-5-methyl-6-oxohexa-2,4dienoate and for 2-hydroxy-6-oxohepta-2,4-dienoate, calculated as the abscissa intercepts of these replots were $1.6 \times 10^{-4}$ and $10^{-4} \mathrm{M}$, respectively. Thus, the different sensitivity of catechol 2,3-dioxygenase to 3-methylcatechol and 4-methylcatechol was not due to the different degree of inhibition exerted by their ring-cleavage products.

\section{Induction of catechol 2,3-dioxygenase}

The capacity of $p$-xylene/ $p$-toluate to induce the meta operon was lower than that of $m$-xylene $/ m$-toluate. Figure 7 shows the induction pattern of catechol 2,3-dioxygenase, 2-hydroxymuconic semialdehyde dehydrogenase, 2-hydroxymuconic semialdehyde hydrolase and 4-oxalocrotonate 

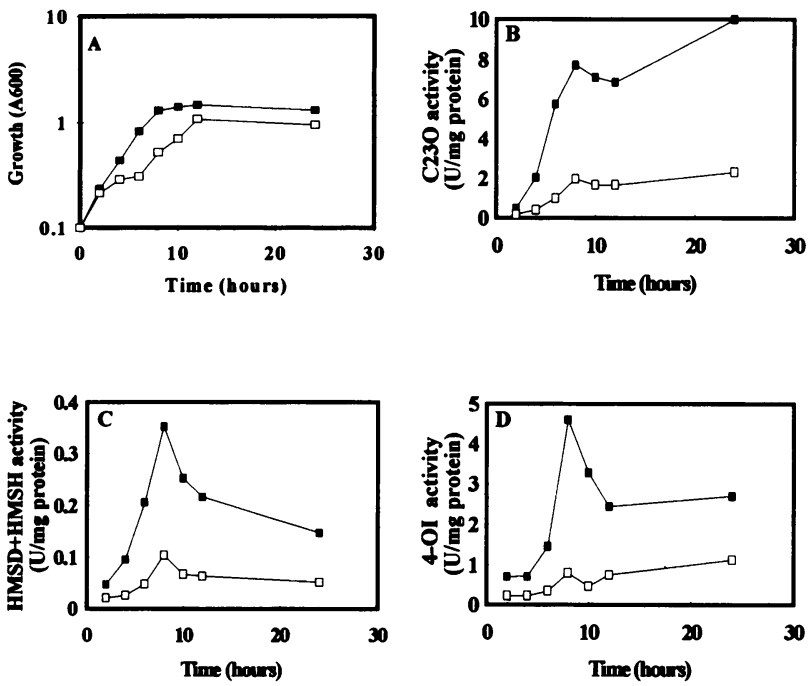

Fig. 7. Induction of meta pathway enzymes by $m$-toluate and $p$-toluate. A culture of KT2440(pWW0-161) was grown overnight in M9 minimal medium containing $10 \mathrm{mM}$ glucose. The overnight culture was diluted into fresh medium containing $5 \mathrm{mM} m$-toluate $(\boldsymbol{D})$ or $5 \mathrm{mM}$ p-toluate ( $\square$ ) as the sole source of carbon. Growth (A) and the activities of catechol 2,3-dioxygenase (B), 2-hydroxymuconic semialdehyde dehydrogenase +2 -hydroxymuconic semialdehyde hydrolase (C) and 4-oxalocrotonate tautomerase (D). For enzyme abbreviations, see Figure 1.

tautomerase in wild-type cells grown in the presence of $m$-toluate or $p$-toluate. The activities of all the enzymes tested were significantly lower ( $\sim$-fold) in cells grown in the presence of $p$-toluate than those grown in the presence of $m$-toluate. This important difference in the induction mediated by $m$-toluate and $p$-toluate was only seen when these aromatic compounds were used as sole sources of carbon and energy. When $m$-toluate or $p$-toluate was added in minimal medium containing glucose or in L-broth, the meta operon was induced at the same level (Table I and our unpublished results).

\section{Discussion}

In order to clarify the physiological role of the $x y l T$ gene encoded by TOL plasmid pWW0, xylT mutants of pWW0 were constructed. P.putida KT2440 containing the $x y l T$ mutants of pWW0 did not grow on $p$-xylene, $p$-methylbenzyl alcohol or $p$-toluate. The inability of the $x y l T$ mutants to grow on $p$-methyl-substituted compounds was due to a deficiency in the regeneration of catechol 2,3-dioxygenase. Apparently, a significant amount of catechol 2,3-dioxygenase is inactivated during the metabolism of 4-methylcatechol, and without the regeneration of catechol 2,3-dioxygenase, cells are not able to metabolize 4-methylcatechol in an amount sufficient for growth. Although catechol 2,3-dioxygenase encoded $x y l E$ gene on the TOL plasmid pWW0 has been extensively studied since 1961 when this enzyme was discovered as one of the first examples of oxygenases (Kojima et al., 1961), the in vivo regeneration of catechol 2,3-dioxygenase was not demonstrated before this study.

Catechol 2,3-dioxygenase consists of four identical subunits of $35 \mathrm{kDa}$ and contains one catalytically essential Fe(II) ion per subunit (Nozaki et al., 1968; Nozaki, 1979; Nakai et al., 1983). From binding and kinetic studies, an ordered Bi Uni mechanism has been proposed in which the enzyme combines first with catechol followed by the binding of oxygen (Hori et al., 1973). Both the catechol and oxygen substrates bind to the catalytic iron which is coordinated to two or more amino acid ligands on the polypeptide (Mabrouk et al., 1991). Catechol 2,3-dioxygenase oxidizes catechol, 3-methylcatechol and 4-methylcatechol (Nozaki et al., 1970; Wallis and Chapman, 1990). However, we have demonstrated that 3-methylcatechol and 4-methylcatechol also act as suicide inhibitors.

It has been demonstrated that the enzyme was inactivated by oxidizing agents but reactivated in the presence of ferrous ions and reducing agents (Nozaki et al., 1968; Bartels et al., 1984). Catechol 2,3-dioxygenase was also inactivated during oxidation of 4-ethylcatechol, but the enzyme inactivated by 4-ethylcatechol could be reactivated in the presence of $\mathrm{FeSO}_{4}$ and ascorbic acid (Wasserfallen, 1989; P.Cerdan, A.Wasserfallen, K.N.Timmis and S.Harayama, manuscript in preparation). These data indicate that the inactivation of catechol 2,3-dioxygenase, in these conditions, was mainly due to the oxidation and/or the removal of the catalytic iron. On the analogy of this interpretation, we infer that 3-methylcatechol and 4-methylcatechol inactivate the enzyme by oxidizing or removing the iron cofactor. Then the XylT product may be involved in the reduction of the oxidized iron cofactor of the enzyme inactivated by 3-methylcatechol, 4-methylcatechol or other agents. In fact, we found that catechol 2,3-dioxygenase inactivated by $\mathrm{H}_{2} \mathrm{O}_{2}$ was reactivated in vivo if the $x y l T$ product was expressed. The $x y l T$ product is most probably a chloroplast-type ferredoxin (Harayama et al., 1991a). We therefore propose that the reduced form of XylT reactivates the inactivated catechol 2,3-dioxygenase by reducing the oxidized iron cofactor. In this reaction, the XylT product itself should be oxidized. The question then arose as to how the oxidized form of XylT is transformed to its reduced form. We have completed the DNA sequencing of the meta operon, and showed that there is no room for a gene which may have a role as electron donor specific to XylT (Harayama and Rekik, 1993). Therefore, a non-specific electron donor may reduce the oxidized XylT protein. For example, the $x y l Z$ gene product, which is an electron donor of toluate 1,2-dioxygenase (Harayama et al., 1991b), may also donate electrons to XylT. Alternatively, electrons may be provided to XylT from an electron transfer system non-specific to the TOL catabolic pathway (e.g. respiratory chain).

After the addition of 3-methylcatechol, in the wild-type and $x y l T$ cultures, the catechol 2,3-dioxygenase activity decreased then reincreased (Figure 3 ). Both the de novo synthesis and reactivation of the enzyme may contribute to the recovery of the catechol 2,3-dioxygenase activity in the wild-type cells, while only de novo synthesis may be involved in the $x y l T$ cells. Such restoration of the enzyme activity was not observed in the $x y l T$ cells after the addition of 4-methylcatechol. This observation suggested that 4-methylcatechol was a more potent inactivator of the enzyme than 3-methylcatechol. This postulation was partly supported by the determination of the rate constants for enzyme inactivation: at a concentration of $5 \mu \mathrm{M}$ 4-methylcatechol was an inactivator 10-fold stronger than 3-methylcatechol (Figure 5).

Another factor which may influence the growth of the $x y l T$ mutants on $m$-methyl- and $p$-methyl-substituted compounds is the difference in the induction of the meta operon by these compounds: we found that $p$-toluate was not as strong an inducer as $m$-toluate (Figure 7 ). Therefore, the amount of 
active catechol 2,3-dioxygenase present in cells grown on $p$-toluate may be lower than that in cells grown on $m$-toluate, and may become a limiting factor in the absence of the XylTdependent regeneration of the enzyme. The intracellular activity of catechol 2,3-dioxygenase in wild-type cells is determined by the rate of synthesis, inactivation and reactivation of the enzyme. In $x y l T$ mutants, the concentration of active enzyme may be determined solely by the rates of synthesis and inactivation of the enzyme. The rate of synthesis of catechol 2,3-dioxygenase may be proportional to the synthesis rate of total proteins, and expressed as: $D \times \mathrm{d} P / \mathrm{dt}$, where $D$ and $\mathrm{d} P / \mathrm{dt}$ represent the fraction of catechol, 2,3-dioxygenase synthetized among the total proteins, and the synthesis rate of total proteins, respectively. If we assume that the inactivation of catechol 2,3-dioxygenase in growing cells occurs principally by suicide catalysis, the rate of inactivation is proportional to the amount of the $E S$ complex, $[E S]$, which is expressed as $E(t) \times[S] /\left([S]+K_{S}\right)$ where $E(t),[S]$ and $K_{S}$ are the total concentration of active enzyme, the concentration of the substrate and the dissociation constant of the substrate, respectively. Under these conditions the rate of enzyme inactivation is expressed as:

$$
\mathrm{d}\left[E^{*}\right] / \mathrm{dt}=k_{\text {inact }} \times[E S]
$$

where $\left[E^{*}\right]$ represents the concentration of the inactivated enzyme and $k_{\text {inact }}$ the rate constant for the enzyme inactivation. If the concentration of catechol 2,3-dioxygenase in growing cells is the limiting factor for the total protein synthesis (which would be the case for $x y l T$ cells growing on $p$-toluate), the catalytic velocity of catechol 2,3-dioxygenase determines the rate of the total protein synthesis:

$$
\mathrm{d} P / \mathrm{dt}=\alpha \times k_{c a t} \times[E S]
$$

where $\alpha$ is a yield of proteins per oxidation of substrate. The change in the intracellular concentration of catechol 2,3-dioxygenase, in this case, is described as:

$$
\mathrm{d}[E(t)] \mathrm{dt}=\left(D \alpha k_{\text {cat }}-k_{\text {inact }}\right) \times[E S]
$$

Equation (3) indicates that the catechol 2,3-dioxygenase concentration increases if $D \alpha \times k_{c a t}>k_{\text {inact }}$. The catechol 2,3-dioxygenase activity in cell extracts of $m$-toluate-induced and $p$-toluate-induced cells were 7 and $1.5 \mathrm{U} / \mathrm{mg}$ protein, respectively (Figure 7). Since the specific activity of purified catechol 2,3-dioxygenase is $400 \mathrm{U} / \mathrm{mg}$ protein (Nakai et al., 1983; Cerdan et al., manuscript in preparation), the $D$ values for $m$-toluate- and $p$-toluate-grown cells were $7 / 400=0.018$ and $1.5 / 400=0.0038$, respectively. It has been shown that E.coli growing on minimal media produces $\sim 0.24 \mathrm{~g}$ of cell materials from $1 \mathrm{~g}$ of carbon substrates, and $\sim 50 \%$ of the cell materials are proteins (Tempest and Neijssel, 1987). Assuming that $1 \mathrm{~g}$ of 3-methylcatechol or 4-methylcatechol produce $0.12 \mathrm{~g}$ of proteins, each $1 \mathrm{~g}(1 / 124 \mathrm{~mole})$ of these catechols produce $2.1 \times 10^{-3}(=0.12 \times 0.018) \mathrm{g}$ and $0.45 \times 10^{-3}(=0.12 \times 0.0038) \mathrm{g}$, respectively, of catechol 2,3-dioxygenase whose molecular weight per subunit is $35 \times 10^{3}$ (Nakai et al., 1983). In other words, 1 mole of 3-methylcatechol and 4-methylcatechol produce $\left(124 \times 2.1 \times 10^{-3}\right) /\left(35 \times 10^{3}\right)$ mole and $(124 \times 0.45 \times$ $\left.10^{-3}\right) /\left(35 \times 10^{3}\right)$ mole, respectively, of catechol 2,3-dioxygenase. The last two values correspond to $D \alpha$ of equation (3). Since $k_{\text {cat }}$ for 3-methylcatechol and 4-methyl- catechol are $480 \mathrm{~s}^{-1}$ and $860 \mathrm{~s}^{-1}$, respectively (Cerdan et al., manuscript in preparation), the $D \alpha k_{\text {cat }}$ values for 3-methylcatechol and 4-methylcatechol became $3.6 \times 10^{-3}$ $\mathrm{s}^{-1}$ and $1.4 \times 10^{-3} \mathrm{~s}^{-1}$, respectively. The $k_{\text {inact }}$ values for 3-methylcatechol and for 4-methylcatechol at a concentration of $5 \mu \mathrm{M}$, are $5 \times 10^{-4} \mathrm{~s}^{-1}$ and $5 \times 10^{-3} \mathrm{~s}^{-1}$, respecttively. This calculation thus explained why the activity of catechol 2,3-dioxygenase in the $x y l T$ mutants was zero when grown on $p$-toluate but increased when grown on $m$-toluate. Thus, the difference in the induction of the meta operon by $m$-toluate and $p$-toluate seems to be another critical factor in determining the growth of the xylT mutants on these substrates.

From the comparison of the primary structure of catabolic enzymes in different degradative pathways, it has been proposed that the recruitment of preexisting enzymes followed by the modification of substrate specificity represent the major mechanism to expand the substrate range of catabolic pathways (Harayama and Timmis, 1992; Harayama et al., 1992). Here a novel mechanism to expand substrate specificity is reported: the XylT-dependent regeneration of inactivated catechol 2,3-dioxygenase allowed sufficient metabolism of 4-methylcatechol to support the growth of host cells on $p$-methyl-substituted compounds.

\section{Materials and methods}

\section{Strain and plasmids}

Strains and plasmids used in this study are listed in Table III.

\section{Media and growth conditions}

M9 minimal medium and L-broth have been described previously (Maniatis et al., 1982; Harayama et al., 1986). Carbon sources and inducers were added to the minimal medium at final concentrations of $10 \mathrm{mM}$ for glucose, $5 \mathrm{mM}$ for $m$-toluate, $p$-toluate and benzoate, or supplied as vapor in the case of toluene, $m$-xylene and $p$-xylene. When required, antibiotics were added at the following final concentrations: Ap, $20 \mu \mathrm{g} / \mathrm{ml} ; \mathrm{Km}, 20 \mu \mathrm{g} / \mathrm{ml}$; $\mathrm{Sp}, 40 \mu \mathrm{g} / \mathrm{ml}$; Tc, $25 \mu \mathrm{g} / \mathrm{ml}$.

\section{Chemicals}

2-Hydroxymuconic semialdehyde, 2-hydroxy-5-methyl-6-oxohexa-2,4-dienoate and 2-hydroxy-6-oxohepta-2,4-dienoate were prepared enzymatically from catechol, 4-methylcatechol and 3-methylcatechol, respectively. 4-Oxalocrotonate was prepared as described previously (Harayama et al., 1984) and stored at $-20^{\circ} \mathrm{C}$ as an ethanolic solution. Aromatic compounds and other reagents were of the highest purity commercially available.

\section{DNA manipulation and genetic methods}

Methods for plasmid isolation, transformation, cleavage by restriction enzymes, ligation and agarose gel electrophoresis have previously been described (Maniatis et al., 1982; Franklin et al., 1983). Matings between E.coli and P.putida were performed as described by Lehrbach et al. (1984). Polymerase chain reaction amplification of the $x y l T$ DNA region was performed by using Vent $t_{R}$ DNA polymerase (Biolabs). Reaction conditions were as described in the manufacturer's instructions. Amplification was carried out by using the primers 5'-ATGAACAGTGCCGGCTACGAG-3' (oligo 1) and 5'-CACGTGACCGCGGCTCATGCG-3' flanking the $x y l T$ region. Direct sequencing of PCR products was performed using the ds DNA Cycle Sequencing System kit (BRL) and oligo 1 as a primer.

\section{Preparation of cell extracts and enzyme assays}

Cultures were grown to late-exponential growth phase in M9 glucose medium containing an inducer (either $m$-toluate or $p$-toluate). Bacterial cells were harvested by centrifugation, washed and resuspended in $100 \mathrm{mM}$ potassium phosphate ( $\mathrm{pH} 7.4)$ containing $10 \%(\mathrm{v} / \mathrm{v})$ acetone, and disrupted by sonication. Assays for 2-hydroxymuconic semialdehyde hydrolase, 2-hydroxymuconic semialdehyde dehydrogenase and 4-oxalocrotonate tautomerase were performed as described previously (Sala-Trepat and Evans, 1971; Harayama et al., 1984). The catechol 2,3-dioxygenase activity was measured according to the method of Sala-Trepat and Evans (1971); the following wavelengths and molar absorption coefficients $\left(M^{-1} \mathrm{~cm}^{-1}\right)$, indicated in brackets, were used: catechol, $375 \mathrm{~nm}(33000)$; 4-methyl- 
Table III. Strains and plasmids used for this study

\begin{tabular}{|c|c|c|}
\hline Strain and plasmids & Relevant markers & Source or reference \\
\hline \multicolumn{3}{|l|}{ Strains } \\
\hline \multicolumn{3}{|l|}{ P.putida } \\
\hline $\begin{array}{l}\text { KT2440 } \\
\text { E.coli }\end{array}$ & PaW1 cured of pWW0 & Franklin et al. (1981) \\
\hline LE392 & $\begin{array}{l}\mathrm{F}^{-} \text {hsdR514 metB1 lacY1 supE44 supF58 galK2 } \\
\text { galT22 trpR55 }\end{array}$ & Maniatis et al. (1982) \\
\hline GSH3491 & $\begin{array}{l}\mathrm{F}^{-} \text {araD139 } \Delta(\text { ara-leu }) 7697 \Delta l a c X 74 \text { galU galK } \\
\text { hsdR rpsE }\end{array}$ & Hugovieux-Cotte-Pattat et al. (1990) \\
\hline \multicolumn{3}{|c|}{ 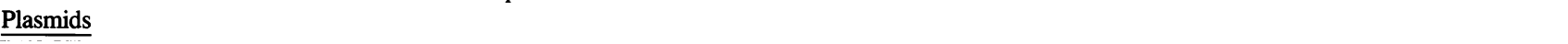 } \\
\hline pACYC184 & $\mathrm{Cm}^{\mathrm{R}} \mathrm{Tc}^{\mathrm{R}}$ & Chang and Cohen (1978) \\
\hline pGA1 & $\begin{array}{l}\text { pACYC184 derivative carrying } 6 \mathrm{~kb} E c o \mathrm{RI}-P s t \mathrm{I} \\
\text { fragment of pWW0 carrying xylXYZLTEG }\end{array}$ & This study \\
\hline pGA2 & $\begin{array}{l}\text { pGA1 derivative carrying a } \mathrm{Km}^{\mathrm{R}} \text { cassette in the } \\
N c o \text { I site within the } x y l T \text { gene }\end{array}$ & This study \\
\hline pGA3 & $\begin{array}{l}\text { pGA1 derivative carrying a } 21 \text { bp linker in the } N c o I \\
\text { site within the } x y l T \text { gene }\end{array}$ & This study \\
\hline pGA4 & $\begin{array}{l}\text { pGA1 derivative in which the } N c o \text { I site within } x y l T \\
\text { is modified by Klenow polymerase filling }\end{array}$ & This study \\
\hline pPL392 & $\begin{array}{l}\text { pBR322 derivative carrying the } \\
x y l X Y Z L T E G F J Q K I H \text { genes of pWw0 }\end{array}$ & Harayama et al. (1984) \\
\hline pRME1 & $\begin{array}{l}\text { pBR322 carrying } 1.2 \mathrm{~kb} \mathrm{HaeII} \mathrm{segment} \mathrm{of} \mathrm{Tn} 903 \\
\text { conferring resistance to } \mathrm{Km} \text { (this insertion is flanked } \\
\text { by synthetic multiple restriction sites) }\end{array}$ & W.Messer provided by $T$.Chakrabarty \\
\hline pWW0-161 & pWW0 carrying Tn $401, \mathrm{Ap}^{\mathrm{R}}, m$-xylene ${ }^{+}, p$-xylene ${ }^{+}$ & Franklin et al. (1981) \\
\hline 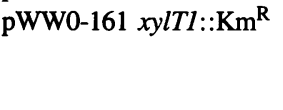 & $\begin{array}{l}\mathrm{Ap}^{\mathrm{R}}, \mathrm{Km}^{\mathrm{R}}, m \text {-xylene } \\
\text { homologous recombination between } \mathrm{pGA} 2 \text { and } \\
\text { pWW0-161 }\end{array}$ & This study \\
\hline pWW0-161 xylT2 & $\begin{array}{l}\mathrm{Ap}^{\mathrm{R}}, \mathrm{Km}^{\mathrm{S}}, m \text {-xylene }{ }^{+}, p \text {-xylene }{ }^{-} \text {obtained by } \\
\text { homologous recombination between pGA3 and } \\
\text { pWW0-161 xylT1:: } \mathrm{Km}^{\mathrm{R}}\end{array}$ & This study \\
\hline pWW0-161 xylT3 & 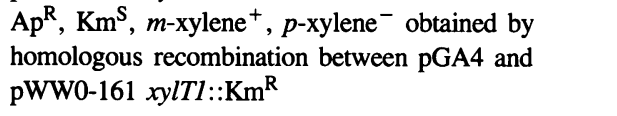 & This study \\
\hline
\end{tabular}

catechol, $382 \mathrm{~nm}$ (28 100); 3-methylcatechol, $388 \mathrm{~nm}$ (13 800). One unit (U) for each enzyme was defined as the amount which transforms $1 \mathrm{mmol}$ of substrate per min.

\section{Purification of catechol 2,3-dioxygenase}

Catechol 2,3-dioxygenase was purified from cultures of KT2440(pWW0-161) and of KT2440(pWW0-161 xylT2) grown overnight in L-broth containing $5 \mathrm{mM} m$-toluate. The purification method was similar to one described previously (Wasserfallen $e t$ al., 1991) except that the final gel filtration step was replaced by a passage through a hydrophobic interaction column (TSK Phenyl 5-PW hydrophobic interaction column; $75 \times 7.5 \mathrm{~mm}$, Bio-Rad Laboratories). Active fractions from DEAE anion-exchange chromatography have been precipitated in ammonium sulfate at $70 \%$ saturation at $4{ }^{\circ} \mathrm{C}$, and precipitated proteins were resuspended in $10 \mathrm{mM}$ ethylenediamine buffer (ED buffer) (pH 7.4) containing $1 \mathrm{M}$ ammonium sulfate at a final concentration of $10 \mathrm{mg} / \mathrm{ml}$. The protein suspension thus prepared was filtered through a Millex filter (pore size $0.2 \mu \mathrm{M}$; Millipore), and charged onto the hydrophobic interaction column pre-equilibrated with ED buffer containing $1 \mathrm{M}$ ammonium sulfate. Proteins were eluted with a linear gradient formed by mixing ED buffer containing $1 \mathrm{M}$ ammonium sulfate and $\mathrm{ED}$ buffer containing $10 \%(\mathrm{v} / \mathrm{v})$ isopropanol.

\section{Determination of kinetic constants for the inactivation of catechol 2,3-dioxygenase}

The method for the determination of the kinetic constants for the inactivation of catechol 2,3-dioxygenase during catalysis is described elsewhere (Cerdan et al., manuscript in preparation). Briefly, the purified enzyme was added to $1 \mathrm{ml}$ of $100 \mathrm{mM}$ potassium phosphate buffer (pH 7.4) containing catechol, 3-methylcatechol or 4-methylcatechol at $50 \mu \mathrm{M}$, and the formation of the ring-cleavage product in this mixture was monitored using a UVICON spectrophotometer (Kontron). The concentration of the enzyme was adjusted so that the complete inactivation of the enzyme occurred before $20 \%$ of the substrate was oxidized. After the initiation of the enzyme reaction, the absorbance increased but the rate of the absorbance change decreased as the enzyme became inactivated. This progress curve was followed for $30 \mathrm{~min}$ and later analyzed using the software Excell (Microsoft). In the analysis, the slope of the absorbance change, $\mathrm{d} A(t) / \mathrm{dt}$, was calculated. The $\mathrm{d} A(t) / \mathrm{dt}$ value is described by the following equation:

$$
\mathrm{d} A(t) / \mathrm{dt}=\epsilon k_{c a t}[S] /\left([S]+K_{S}\right) \times E_{\mathrm{o}} \exp \left\{\left(-k_{\text {inact }} \times t \times[S]\right) /\left([S]+K_{S}\right)\right\}
$$

where $\epsilon, k_{c a t},[S], K_{S}, E_{\mathrm{o}}$ and $k_{\text {inact }}$ are the extinction coefficient of the product, the rate constant for the productive catalysis (ring-cleavage), the concentration of the substrate, the dissociation constant, the initial concentration of the enzyme and the rate constant for the enzyme inactivation, respectively. Since the substrate concentration used in the present experiments $(50 \mu \mathrm{M})$ was significantly higher than the $K_{S}$ value $(<3 \mu \mathrm{M}),[S] /([S]+$ $K_{S}$ ) was equal to 1 . The logarithm of the above equation is then given as:

$$
\log \{\mathrm{d} A(t) / \mathrm{dt}\}=\log \epsilon k_{c a t} E_{\mathrm{o}}-k_{\text {inact }} \times t
$$

Thus, the $k_{\text {inact }}$ value could be obtained from the slope of $\log \{\mathrm{d} A(t) / \mathrm{dt}\}$ plotted against $t$.

In vivo reactivation of catechol 2,3-dioxygenase inactivated by $\mathrm{H}_{2} \mathrm{O}_{2}$

KT2440(pWW0-161) and KT2440(pWW0-161 xylT1) cells were grown at $30^{\circ} \mathrm{C}$ in $\mathrm{M} 9$ minimal medium containing glucose and $m$-toluate. The cells were harvested, washed and resuspended in an equal volume of $0.1 \mathrm{M}$ potassium phosphate buffer (pH 7.4). To $4 \mathrm{ml}$ of the cell suspension, $50 \mu \mathrm{M}$ of $\mathrm{H}_{2} \mathrm{O}_{2}$ was added, and incubated at room temperature. At different times, $100 \mu \mathrm{l}$ aliquots were taken, and their catechol 2,3-dioxygenase activities were determined in $0.1 \mathrm{M}$ potassium buffer ( $\mathrm{pH} 7.4)$ containing $600 \mu \mathrm{M}$ catechol by measuring the change in absorbance at $375 \mathrm{~nm}$. The catechol 2,3-dioxygenase activity determined using intact cells gave almost identical values to those determined using sonicated cell extracts. 


\section{Acknowledgements}

We thank William Kelley for careful reading of the manuscript. This study was supported by the Swiss National Science Foundation.

\section{References}

Bartels,I., Knackmuss,H.J. and Reineke,W. (1984) Appl. Environ. Microbiol., 47, 500-505.

Bartilson,M., Nordlund,I. and Shingler,V. (1990) Mol. Gen. Genet., 220 , 294-300.

Bruschi,M. and Guerlesquin,F. (1988) FEMS Microbiol. Rev., 54, $155-176$.

Chang,A.C. and Cohen,S.N. (1978) J. Bacteriol., 134, 1141-1156.

Franklin,F.C., Bagdasarian,M., Bagdasarian,M.M. and Timmis,K.N. (1981) Proc. Natl. Acad. Sci. USA, 78, 7458-7462.

Franklin,F.C., Lehrbach,P.R., Lurz,R., Rueckert,B., Bagdasarian,M. and Timmis,K.N. (1983) J. Bacteriol., 154, 676-685.

Harayama,S. and Rekik,M. (1990) Mol. Gen. Genet., 221, 113-120.

Harayama,S. and Rekik,M. (1993) Mol. Gen. Genet., in press.

Harayama,S. and Timmis,K.N. (1992) In Sigel,H. and Sigel,A. (ed.), Metal Ions in Biological Systems. Marcel Dekker Inc., Vol. XXVIII, pp. $100-151$.

Harayama,S., Lehrbach,P.R. and Timmis,K.N. (1984) J. Bacteriol., 160, $251-255$.

Harayama,S., Leppik,R.A., Rekik,M., Mermod,N., Lehrbach,P.R., Reineke,W. and Timmis,K.N. (1986) J. Bacteriol., 167, 455-461.

Harayama,S., Mermod,N., Rekik,M., Lehrbach,P.R. and Timmis,K.N. (1987) J. Bacteriol., 169, 558-564.

Harayama,S., Rekik,M., Wubbolts,M., Rose,K., Leppik,R.A. and Timmis,K.N. (1989) J. Bacteriol., 171, 5048-5055.

Harayama,S., Polissi, A. and Rekik,M. (1991a) FEBS Lett., 285, 85-88.

Harayama,S., Rekik,M., Bairoch,A., Neidle,E.L. and Ornston,L.N. (1991b) J. Bacteriol., 173, 7540-7548.

Harayama,S., Kok,M. and Neidel,E.L. (1992) Annu. Rev. Microbiol. , 46, $565-601$.

Hori,K., Hashimoto,T. and Nozaki,M. (1973) J. Biochem., 71, 375-381.

Hugovieux-Cotte-Pattat,N., Köhler,T., Rekik,M. and Harayama,S. (1990) J. Bacteriol., 172, 6651-6660.

Kojima,Y., Itada,N. and Hayaishi,O. (1961) J. Biol. Chem., 236, 2223-2230.

Lehrbach,P.R., Zeyer,J., Reineke,W., Knackmuss,H.J. and Timmis,K.N. (1984) J. Bacteriol., 158, 1025-1032.

Mabrouk,P.A., Orville,A.M., Lipscomb,J.D. and Solomon,E.I. (1991) J. Am. Chem. Soc., 113, 4053-4061.

Maniatis,T., Fritsch,E.F. and Sambrook,J. (1982) Molecular Cloning. A Laboratory Manual. Cold Spring Harbor Laboratory Press, Cold Spring Harbor, NY.

Nakai,C., Kagamiyama,H., Nozaki,N., Nakazawa,T., Inouye,S., Ebina,Y. and Nakazawa,A. (1983) J. Biol. Chem., 258, 2923-2928.

Nakazawa,T., Inouye,S. and Nakazara,A. (1980) J. Bacteriol., 144, $222-231$.

Nordlund,I., Powlowski,J. and Shingler,V. (1990) J. Bacteriol., 172, 6826-6833.

Nozaki,M. (1979) Top. Curr. Chem., 78, 145-186.

Nozaki,M., Ono,K., Nakazawa,T., Kotani,S. and Hayaishi,O. (1968) J. Biol. Chem., 243, 2682-2690.

Nozaki,M., Kotani,S., Ono,S. and Senoh,S. (1970) Biochem. Biophys. Acta, 220, 213-223.

Sala-Trepat,J.M. and Evans,C.W. (1971) Eur. J. Biochem., 20, 400-413. Shingler,V., Powlowsky,J. and Marklund,U. (1992) J. Bacteriol., 174, 711-724.

Tempest,D.W. and Neijssel,O.M. (1987) In Neidhardt,F.C. (ed.), Escherichia coli and Salmonella typhimurium Cellular and Molecular Biology. ASM Press, Washington DC, Vol I, pp. 797-806.

Wallis,M.G. and Chapman,K. (1990) Biochem. J., 266, 605-609.

Wasserfallen,A. (1989) Ph.D thesis, University of Geneva.

Wasserfallen,A., Rekik,M. and Harayama,S. (1991) Bio Technology, 9, 296-298.

Worsey,M.J. and Williams,P.A. (1975) J. Bacteriol., 124, 7-13.

Yen,K.M. and Gunsalus,I.C. (1982) Proc. Natl. Acad. Sci. USA, 79, 874-878.

You,I.S., Ghosal,D. and Gunsalus,I.C. (1991) Biochemistry, 30, $1635-1641$.

Received on February 24, 1993; revised on April 26, 1993 